\title{
An Examination of U.S. Presidential Candidates and How They Mobilize Youth
}

\author{
Michael Pomante \\ Tulane University, New Orleans, LA, USA \\ Email: pomantem@gmail.com
}

How to cite this paper: Pomante, $M$ (2017). An Examination of U.S. Presidential Candidates and How They Mobilize Youth. Open Journal of Political Science, 7, 473-487.

https://doi.org/10.4236/ojps.2017.74037

Received: August 22, 2017

Accepted: September 26, 2017

Published: September 29, 2017

Copyright (c) 2017 by author and Scientific Research Publishing Inc. This work is licensed under the Creative Commons Attribution International License (CC BY 4.0).

http://creativecommons.org/licenses/by/4.0/

\section{(c) (i) Open Access}

\begin{abstract}
It is well known that American youth, those 18 - 24 years old, have abysmal turnout rates in all elections. Despite the traditional poor performance of this age group, there have been several presidential elections (1992 and 2008) where their turnout has been significantly higher than average. The objective of this research is to explore aspects of U.S. presidential candidates and their campaign activities which lead to higher rates of youth mobilization. Through an examination of newspaper articles over four presidential election cycles, the research uncovers that younger candidates who use new methods of engagement positively influence the turnout rate of youth. Elections which had the greatest levels of youth turnout had significantly younger candidates whose campaigns directly targeted youth through new means. On the other hand, the two elections with the lowest levels of youth mobilization lacked younger candidates whose campaigns failed to actively court young voters in any way.
\end{abstract}

\section{Keywords}

Presidential Election, Presidential Candidates, Youth, Mobilization, Voter Turnout

\section{Introduction}

With the conclusion of the 2016 presidential election, Hillary Clinton and the Democrats are left to question why she failed to mobilize the same groups Obama was successful with. One of the demographic groups which are commonly given credit in helping Obama win the election in 2008 is youth. Since the passage of the $26^{\text {th }}$ Amendment, turnout of those between the ages of 18 and 24 has ranged from a low of 32.3 percent (1996 and 2000) to a high of 44.3 percent (2008) in presidential elections. Knowing the turnout rate of youth in presiden- 
tial elections is traditionally low, presidential candidates recognize that if they can mobilize this traditionally apathetic population, it can help secure a win. Using many of the same tactics as Obama, Hillary Clinton attempted, but failed to mobilize this important population. So, the questions Democrats are left with are: what can a presidential candidate do to mobilize young American voters and what contributes to youth's excessive swings in turnout? Through an in-depth analysis of newspaper accounts of four presidential elections, this research finds several contributing factors which influence political participation amongst youth. Throughout the research, the term "youth" references individuals who are 18 - 24 years of age.

With only a few exceptions, the general trend in youth's participation at the polls has been declining since the passage of the $26^{\text {th }}$ Amendment. This continued decline has been associated with youth's lack of knowledge associated with information distributed in the media (Wattenberg, 2012), and civic education (Galston, 2001; 2004). Arguably, youth may be less informed than others in the past however, it still does not completely explain the significant low levels of turnout for this group. I believe additional contributing factors to youth's low level of participation on Election Day are largely dependent upon the connection made between this group and the presidential candidates. If a better connection is made between the candidate and youth, they will be more likely to vote. This research reveals that a connection is created through two specific means, first, through identity and second, through mobilization efforts. In the end, this analysis suggests that the mobilization of youth and the age of the presidential candidates help explain the variation in youth voter turnout in presidential elections.

\section{Explaining Youth Political Participation}

Social Identity Theory (SIT) suggests individuals will be more likely to vote for and support candidates who share similar characteristics with themselves (Conover, 1984; Greene, 1999; Huddy, 2001; Oakes, 2002; Tajfel et al., 1971). The connection with a candidate's identity has been shown to increase the participation rates among women (Bassi, Morton, \& Williams, 2011; Dolan, 1998; Matson \& Fine, 2006), African Americans (Bobo \& Gilliam Jr., 1990), Latinos (Jackson, 2011), and more recently youth (Pomante \& Schraufnagel, 2015). Using SIT as a starting point, this article seeks to expand on previous research applying SIT to youth mobilization.

Pomante and Schraufnagel (2015) demonstrate that young Americans' likelihood of voting increases when one candidate is younger and challenged by an older individual. Although the Constitution allows for candidates as young as 35 to run for the Presidency, the mean age of presidential candidates since 1972 is 58.8. With such a high mean age, it seems reasonable youth would have difficulty identifying with a candidate of this age and, therefore, be less likely to turn out to vote. However, the lack of identity cannot be the only reason for the low levels 
of youth political participation in presidential elections.

Youth today are increasingly more likely to identify as independents or weak identifiers of either party when asked to identify (Kaufmann, Petrocik, \& Shaw, 2008: 131), which, in turn, makes it more unlikely that they will turn out on Election Day (Leighley \& Nagler, 2014: 159). Previous research has shown that, once an individual identifies with a party, they are more likely to continue to identify with the party throughout the rest of their life (Campbell et al., 1980: 148). Regardless of how an individual is mobilized to vote, once they participate, they are more likely to become habitual voters and continue to vote in future elections (Plutzer, 2002).

Both parties believe that youth are the key to their party's longevity and strength, however, only about two-fifths of local party leaders give priority to mobilizing young voters (Shea \& Green, 2007: 21). Although parties state that youth are important, for the most part they have stopped grassroots mobilization of nonvoters (Shea \& Green, 2007: 27). This is because party leaders' today focus on mobilizing those they know will, firstly, show up and secondly, vote for their party (Holbrook \& McClurg, 2005). Youth, for the most part, lack both of these characteristics and are, therefore, not highly targeted in direct mobilization efforts. With such low rates of turnout, politicians are unlikely to focus large sums of money on this group because it is not known if young people will even turn out at the polls. Not only do youth show up at abysmal rates, as individuals they lack the voting history that the parties rely on in order to determine which party they will vote for. Yet, as this investigation will reveal, those candidates who have actively pursued the vote of youth have been rewarded with high turnout of this age group, garnering a vast majority of those votes.

Even though youth are not likely to strongly identify with one party or another when asked, they are overwhelmingly showing support for one party over another when they go to cast their vote. Kaufmann, Petrocik and Shaw (2008: 138) reveal "the younger cohorts have voted increasingly Democratic from the 1980 s to the 2000s". Such overwhelming support for one party over another is not traditionally seen at the polls (Verba, Scholzman, \& Brady, 1995). For example, Verba, Scholzman and Brady (1995) find that Democrats and Republicans turn out at approximately the same rate in both national and local elections (Zoltan \& Trounstine, 2005: 518). Yet, this trend does not hold when examining the youngest age group in the electorate. The 18 to 24 year old age group tends to show up at the polls at dramatically lower rates than older age groups, and then tends to support the Democratic Party at higher rates than the rest of the voting population. For these reasons, it seems the Democrats have much more to gain in the mobilization of youth when compared to Republicans.

The mobilization of youth by presidential candidates and their parties must be taken seriously. With such a large portion of this group typically abstaining from voting, concerted efforts by campaigns to involve and reach out to this group could tip a relatively close race in their favor. 


\section{Case Selection and Findings}

Because U.S. presidential elections only take place once every four years and youth only received the right to vote in 1972, the number of observations from which to draw conclusions is limited. Due to the lack of instances, a quantitative analysis is ineffective and unlikely to identify any new insights into the mobilization of this traditionally poor performing group. In an effort to identify new theories explaining the variation in their turnout, I turn to an in-depth examination of newspaper accounts of four presidential elections. Collection of newspaper articles was gathered using Lexis-Nexis Academic.

Each presidential election in the analysis has been chosen from elections dating back to 1976, based upon the dependent variable, youth voter turnout. The turnout of 49.6 per cent for 1972 has been excluded because the value is an outlier and is thought to be so high because this election was the first election that 18 - 20 years old were able to vote. Two elections were chosen with the highest rates of youth turnout, and two additional races with the lowest levels of youth turnout. It is expected that the two races which saw significantly higher rates of youth turnout will share similar characteristics while the two races which had significantly low rates of youth turnout will be void of these characteristics. Table 1 reports the turnout, election years, and the difference in age between the two major party candidates, for the four cases chosen. Two cases (2000 \& 2008) were identified by Pomante and Schraufnagel (2015: 490-491) as having the highest and lowest turnout of youth, with the correlating age gaps.

By examining the data in Table 1, affirming evidence can be found for the research conducted by Pomante and Schraufnagel (2015). In three of the four cases selected, the age gap between presidential candidates correlates with aggregate turnout rates of 18 - 24 year-old. The two elections which stand out for their higher than average youth voter turnout, 1992 and 2008, also had significant age gaps between the candidates. In 1992, President George H.W. Bush was running against Arkansas Governor Bill Clinton. Turnout of youth in this election was the highest since the seminal election in 1972, at 42.1 percent of the voting eligible population that were 18 to 24 years of age. Importantly, the age gap between

Table 1. Youth voter turnout and candidate age difference in presidential elections: 1976-2008.

\begin{tabular}{ccc}
\hline Year & Youth voter turnout & Candidate age difference \\
\hline & Record high turnout & \\
1992 & 42.1 & 22 \\
2008 & 44.3 & 25 \\
& Record low turnout & 23 \\
1996 & 34.3 & 2 \\
2000 & 32.3 & \\
\hline
\end{tabular}

Source of voter turnout data: U.S. Census Bureau. 
the two major party candidates was significant. Bill Clinton was 46 and George H.W. Bush was 68 on Election Day, resulting in a 22-year age gap. Then in 2008, turnout of the 18 - 24 year-old group once again reached a much higher than average level. In this election, a 47 year-old Barack Obama was running against 72 year-old John McCain. Although 46 and 47 may not sound especially young, when the group being analyzed does not exceed 24 years of age, these ages are considerably below average for presidential candidates. The average age for presidential candidates is 58.8 years of age with a standard deviation of 8.5 years. So, both Clinton and Obama were more than one standard deviation younger than the average candidate while the age of their challengers where also more than one standard deviation higher than average. Theoretically, a significant spread in age between major party candidates makes the uncommon age of each individual more salient with the younger voting public.

However, as previously noted the relationship between the age gap and youth voter turnout only works for three of the four elections. With the 1996 election failing to conform to expectations, it suggests that something else may be contributing to variation in youth turnout. Although it is theoretically possible that age primarily drives the increase in turnout among youth in these elections, there may be other factors which contribute to their mobilization. As will be shown it is possible that age is an antecedent variable for a candidate's mobilization efforts of college-aged voters. To try and obtain a better understanding of the true causal process, if one exists, I use an analysis of newspaper reports on each of the relevant election cycles using the on-line search engine Lexis-Nexis.

For both the 1992 and 2008 elections, several searches were conducted for articles addressing the "presidential election and youth turnout" along with searches which used the candidate's name "and young voters" in the relevant election year. Specifically, the search parameters were from January 1 to December 31 and included "Bill Clinton and young voters", "George Bush and young voters", "Barack Obama and young voters", and "John McCain and young voters". The first search returned one article in 1992 and 62 articles in 2008. This suggests that youth voter turnout was a much more salient topic in 2008 than it was in 1992. When each candidate's name was entered along with "young voters" a much larger number of articles were generated.

Table 2 displays article counts for each of the different searches conducted in 1992.In 1992, there was only one article specifically addressing the presidential election and youth turnout that year. The article recognizes, the day after the

Table 2. Newspaper article results and search terms for the 1992 presidential election.

\begin{tabular}{cc}
\hline Search terms for 1992 (Jan. 1-Dec. 31) & Number of news articles \\
\hline Presidential election and youth turnout & 1 \\
Bill Clinton and young voters & 108 \\
George Bush and young voters & 75 \\
\hline
\end{tabular}

Source: LexisNexis Academic. 
election, that Bill Clinton's pitch to younger and first-time voters paid off with record youth voter turnout (USA Today, 1992). Although the expected turnout of youth did not gain any significant attention by the media prior to the election, the media continually noted Clinton's effort to connect with young voters. When examining the amount of media attention each individual gave to the youngest voters, Clinton was referenced with young voters in 108 articles, whereas Bush was only referenced in 75 articles. However, these numbers do not tell the whole story. The articles with Clinton were overwhelming positive, with discussions about how he is trying to connect with youth. Articles which mentioned both President Bush and "young voters" talked about his lack of willingness to appear at venues which bring in younger crowds.

Of particular note, several articles allude to the idea that 1992 was a critical election for young Americans (for a discussion of critical elections see Key, 1955; Sundquist, 1973). Immediately prior to this election, in the 1980s, a majority of young voters had consistently been voting for the Republican Party (The Washington Post, 1992). While examining many of these articles, it is reasonable to assume that the shift in party support among young voters, which took place in 1992, is largely due to the attention Clinton gave this age group. During his campaign, Governor Clinton appeared on television networks such as MTV and late-night talk shows such as the Arsenio Hall Show (St. Louis Post-Dispatch, 1992). While Clinton was appealing to youth in their domains, President Bush and his campaign expressed that he would never go on any shows like that and, "... at 68, he was too old to become a teeny-bopper" (The Globe and Mail,1992). In newspaper reports, the Bush campaign acknowledged that youth get the message that he is out of touch, that he fails to connect with what their life is about (The Atlanta Journal and Constitution, 1992), and that their generation has been forgotten or dismissed by national leaders (St. Louis Post-Dispatch, 1992a).

Bill Clinton's attempts to connect with this population went beyond appearing on certain television shows. Governor Clinton visited college campuses, such as University of New Mexico (UNM), and had a much better organization for registering voters of all ages. When Clinton visited UNM, a total of 4114 new voters were registered, with only 40 of that total registering as Republicans (The Guardian, 1992). Just over a month before the election, the Clinton campaign was signing up 200 volunteers a day at Ohio University (The Guardian, 1992). Although President Bush seemed to be ignoring the youth population, it was believed that Vice President Dan Quayle was popular with younger voters and should have helped shore up this segment of the potential voting population in the Midwest (The Washington Post, 1992a). This may have been the case in 1988 when younger voters favored the Republicans, but with the actions of the Bush administration during its time in office and its lackluster desire to connect with these voters in 1992, just having a younger vice-presidential running mate did not seem sufficient to persuade many youth to stay with the Republican Party.

While Bush seemed to be ignoring young voters, newspaper reports suggested 
the College Republicans organization was actively working on his behalf. The organization took a one-on-one approach when it came to recruiting, and criticized the media for its lack of fairness in their coverage of their conservative beliefs (The Globe and Mail, 1992a). In the end, strategies by Bush and the Republican Party failed to connect with the youngest voting population, creating a perception of a greater effort on Clinton's behalf. In hindsight, the new strategies of the Clinton campaign and the impact of MTV's Rock the Vote may have greater explanatory power than candidate age or the age gap. Rock the Vote was founded in 1990 with the goal of increasing turnout among 18 to 24 year-olds. 1992 was the first election in which Rock the Vote actively worked to register potential voters. It remains to be seen if candidate age alone, without a concerted mobilization effort, will be sufficient to increase youth voter turnout. I turn now to an analysis of the 2008 campaign, which also had a young candidate, a large age gap, and a strong youth mobilization strategy.

The findings reported by Pomante and Schraufnagel (2015) demonstrate that age is sufficient for mobilization, but evidence from the 1992 and 2008 presidential elections suggest that there might be other conditions, in national elections, which have led to the record turnout of youth and its overwhelming support for the Democratic Party. It will be the analysis of the control cases that demonstrate more completely the way the age of candidates' influences youth voter turnout in these real-world scenarios.

In 2008, Barack Obama and John McCain were in the battle for the White House. With high youth turnout being credited for helping Bill Clinton win the presidency in 1992, the media gave significant attention during the 2008 presidential campaign to candidates who appeal to the youngest voting segment, as is evident from the findings reported in Table 3. Overall, there were 62 news articles which discussed the turnout of youth, with most of these articles focusing on whether or not it was going to be another record turnout on Election Day. Articles written after the election gave reasons why it had reached record levels. The amount of attention which was given to each candidate and their appeals to the youngest voting group increased greatly from 1992, with Barack Obama being identified with young voters in 1939 articles, 150 percent more than John McCain.

It seems that candidate Obama had studied youth and had some understanding of the reasons why youth turned out in record numbers in 1992 and why they had failed to turnout for Al Gore in 2000. Regardless of what knowledge he

Table 3. Newspaper article results and search terms for the 2008 presidential election.

\begin{tabular}{cc}
\hline Search terms for 2008 (Jan. 1-Dec. 31) & Number of news articles \\
\hline Presidential election and youth turnout & 62 \\
Barack Obama and young voters & 1939 \\
John McCain and young voters & 1290 \\
\hline
\end{tabular}

Source: LexisNexis Academic. 
had, Barak Obama put into place many initiatives that mobilized young voters like no other presidential candidate in the contemporary period. Obama engaged youth in their environment and with technology, both on Facebook and text messaging (Sarasota Herald-Tribune, 2008). Obama spent a considerable amount of time on university campuses and at the beginning of October in 2008, Michelle Obama, the presidential candidate's wife visited the University of Colorado campus in a concerted effort to mobilize young Americans (Daily Camera, 2008). Her topic of choice was the burden of paying off student loans and how she and Barack Obama had just finished paying off their own loans. Additionally, Joe Biden, the Democratic vice-presidential candidate, visited college campuses in Florida to increase youth turnout in a "must win" state (Sarasota $\mathrm{He}$ rald-Tribune, 2008).

Obama's youth mobilization efforts did not stop with campus visits, he also spent a considerable amount of money on youth mobilization, sending youth volunteers to campaign workshops across the country in order to educate them on campaign work and organization. While McCain's campaign failed to organize college volunteers in states like Wisconsin, Obama had over 100 students educated, through a workshop in Milwaukee, early in the campaign (The Capital Times, 2008).

Overall, the articles which mentioned John McCain in 2008 noted how his campaign was not actively targeting youth. The overwhelming number of these articles also mentioned Senator Obama and compared each candidate's appeal to this voting group. Each of these articles mentioned McCain's lack of support among young voters. The few positive mentions of McCain and youth focused around his message concerning global warming (The Philadelphia Daily News, 2008), as well as his selection of a younger "hockey mom" as his vice-presidential running mate (Pittsburgh Post-Gazette, 2008). Yet, without a direct appeal to youth, any opportunity that might have existed with this group was lost.

The analysis of the 1992 and 2008 elections show that in addition to a young candidate running, the younger candidate also employed extensive mobilization efforts targeted at youth. An analysis of these two elections, seem to show that actively pursuing the youth vote by candidates can mobilize this traditionally poor performing group. But just as importantly, these two elections suggest that age might not be the only factor which increases youth turnout. Yet, nothing in the analysis of newspaper reports suggests that the youth of the candidate is not an important predictor of whether a candidate will work to mobilize youth at greater than average rates. All that being said, I move next to an analysis of the presidential elections with the lowest youth turnout, 1996 and 2000.

In 1996, only 34.3 percent of eligible 18 - 24 year-old voters cast a ballot and in 2000 , turnout decreased slightly to 32.3 percent. As with the previous two elections, a Lexis-Nexis search for each election was conducted with the same key phrases "presidential election and youth turnout", as well as candidates' names in each election cycle with "young voters". Table 4 reports the number of articles for each of the search criteria. With the record turnout in 1992, the media 
Table 4. Newspaper article results and search terms for the 1996 presidential election.

\begin{tabular}{cc}
\hline Search terms for 1996 (Jan. 1-Dec. 31) & Number of news articles \\
\hline Presidential election and youth turnout & 1 \\
Bill Clinton and young voters & 89 \\
Bob Dole and young voters & 69 \\
\hline
\end{tabular}

Source: LexisNexis Academic.

still did not give much attention to youth in 1996 with the search of "presidential election and youth turnout", returning only one article.

In 1996, President Bill Clinton was running for re-election against Bob Dole. Although high youth turnout was credited for President Clinton's win in 1992, the media still did not give significant attention to this particular voting segment in his re-election campaign. Only one article was written mentioning the election and youth turnout levels. Another surprising element is the number of articles that discussed President Clinton and young voters. In 1996, there was a decrease of 18 percent in the number of articles that mentioned President Clinton and this youngest voting population from his first presidential campaign. This decrease is suggestive of the decline in the Clinton campaign to mobilize and connect with youth. Overall, by looking at the number of articles written about each candidate, neither really sought to connect with this voting segment. Political experts were well aware that neither of the main party candidates were appealing to the young generation (The New York Times, 1996).

The 1996 election was the second presidential election that MTV's Rock the Vote was actively working to get younger people to vote. With the supposed lessons learned by the Republican Party in the 1992 election, Bob Dole tried to connect better with youth by appearing on MTV's Choose or Lose bus. However, this did not work well for him and commentators claimed the appearance just made him look like an "old dinosaur", failing to create any positive connection with potential young voters (The Guardian, 1996). Regardless of this attempt, Dole was still perceived by young Americans as not putting forth any effort to reduce the generational gap between himself and potential youth voters (Lincoln Journal Star, 1996). While Dole failed in his attempt to connect with youth, Clinton was also giving it only a half-hearted attempt.

It seems the huge impact that Clinton had with this segment of the population in 1992 made him complacent in 1996, taking young voters for granted (The Philadelphia Inquirer, 1996). Such sentiments were echoed by youth, noting that the politicians are not speaking their language or addressing their issues (Lincoln Journal Star, 1996). The low turnout of youth in 1996 was foreshadowed by reports that young voters were largely disappointed in the work of the Clinton Administration (USA Today, 1996). Additionally, in 1996 the approach that the Clinton campaign used to connect with this voting population was almost a rerun of the 1992 election. Specifically, Clinton went on MTV and other talk shows but failed to do anything new to connect. It seems, based on comments 
made in the media, that youth found these attempts boring and that they, consequently, disengaged in the electoral process (Lincoln Journal Star, 1996).

In 2000, the media started to pick up on the importance of young voters, as can be seen by the search results reported in Table 5. For example, the search of "presidential election and youth turnout" returned 64 articles, as opposed to the previous search results of one article for 1996. Additionally, each candidate saw an increase in the number of articles in which they were mentioned with young voters. With the potential to learn so much from the 1992 and 1996 election cycles, it is surprising the candidates in 2000 did not try to engage youth at a greater rate. As the narrative continues, it will be clear that many of these articles painted a bleak picture about the connection between the candidates and individuals between the ages of 18 and 24 .

After the election, some journalists believed that the historically close election between $\mathrm{Al}$ Gore and George W. Bush in 2000 could have swung one way or the other, if either candidate would have focused less on family values and not ignored issues of importance to younger single individuals (Pittsburgh Post-Gazette, 2000) who failed to turn out to vote at an alarming rate. At one point, Al Gore attempted to connect with youth, by having his 27-year-old daughter address potential young voters at the Democratic National Convention. Nevertheless, this attempt failed because instead of focusing on topics important to youth, she focused on her baby and the future of young children. Another failed attempt by the Gore campaign was the website (gorenet.com) which his campaign set up to energize young voters (Ledger, 2000). Its inability to mobilize could have been due to the website being before its time, or that a just having website targeting college-aged individuals is too little to mobilize this group. However, it was not only $\mathrm{Al}$ Gore who could not connect with the youth, both candidates failed to gain any traction with the youngest voting bloc.

When it comes to Bush's appeal to young voters the news reports reveal a similar strategy as Gore's. In an attempt to get young voters onboard with the Bush campaign, his handlers deployed his nephew George P. Bush (The Straits Times, 2000). George P. Bush was a young, attractive man born with a Mexican mother. Although Governor Bush pushed his nephew to connect with young voters, his nephew made the same mistake as Gore's daughter. When interacting and talking with young voters he emphasized his uncle's commitment to family, failing to address any issues which were important to young single individuals

Table 5. Newspaper article results and search terms for the 2000 presidential election.

\begin{tabular}{cc}
\hline Search terms for 2000 (Jan. 1-Dec. 31) & Number of news articles \\
\hline Presidential election and youth turnout & 64 \\
Al Gore and young voters & 131 \\
George Bush and young voters & 148 \\
\hline
\end{tabular}

Source: LexisNexis Academic. 
(The Straits Times, 2000). One can easily imagine that issues such as employment after graduation, college affordability, and student loans would easily resonate with this population.

These attempts at connecting with youth were failures for two reasons. First, neither candidate attempted to connect with the youngest voters themselves, instead sending family members. Secondly, the messages conveyed a disregard for young single people and their issues, focusing instead on young families. With each of these attempts, both candidates sent the same message to youth single voters. Specifically, young voters were not important because the candidates themselves could not be bothered to interact with or address issues which were important to this group. The lack of appeal to this group was greatly noticed since approximately 65 percent of advertising, by both candidates, was specifically targeted toward the 50 and older crowd (The Ottawa Citizen, 2000).

Table 6 reports a qualitative summary of the four presidential elections examined. Each table lists each candidate, their age on Election Day, the extent of their campaign's youth mobilization efforts, and whether or not a new Get Out The Vote Campaign (GOTV) was embraced.

The combination of elections and candidates examined here shed light on three possible explanations of whether or not youth turnout at higher than average rates on Election Day. First, there must be a nominee which is significantly younger than the average presidential candidate, with the other nominee being significantly older. Second, youth voters must actively be appealed to, addressing issues and concerns which are important to them. And third, a new method must be embraced by a candidate in their GOTV campaign. Most clearly, the

Table 6. Qualitative summary of presidential elections examined.

\begin{tabular}{|c|c|c|c|}
\hline & Age & Youth mobilization effort & New GOTV campaign \\
\hline \multicolumn{4}{|l|}{ High turnout races } \\
\hline \multicolumn{4}{|l|}{1992} \\
\hline Bill Clinton & 46 & High & Yes \\
\hline George H.W. Bush & 68 & Low & No \\
\hline \multicolumn{4}{|l|}{2008} \\
\hline Barack Obama & 47 & High & Yes \\
\hline John McCain & 72 & Low & No \\
\hline \multicolumn{4}{|l|}{ Low turnout races } \\
\hline \multicolumn{4}{|l|}{1996} \\
\hline Bill Clinton & 50 & Moderate & No \\
\hline Bob Dole & 73 & Low & No \\
\hline \multicolumn{4}{|l|}{2000} \\
\hline Al Gore & 52 & Low & No \\
\hline George H.W. Bush & 54 & Low & No \\
\hline
\end{tabular}


evidence suggests that there must also be a mobilization effort in addition to a large age gap between the candidates in order to increase the rates at which youth turnout.

\section{Discussion}

The analyses of these four presidential elections reveal important insights into the mobilization of youth. Evidence suggests, that at the presidential level, the age of the candidate dictates their willingness and effort to directly appeal to young voters. At ages 45 and 46, both Bill Clinton and Barack Obama were willing to try innovative ways to connect with first time voters. However, as seen in Bill Clinton's reelection campaign, at the age of 50, his willingness to engage with this population decreased. It seems, therefore, as if age plays two parts in the mobilization of young people. Firstly it acts an identity cue and secondly as an antecedent to the efforts of the candidate to engage with this population.

Politicians must also remember that the concerns of those between the ages of 18 and 24, are significantly different to those aged 25 and older. Failure to acknowledge and address the issues that are important to this group creates the perception that their issues do not matter. If presidential candidates are consistently addressing topics important to young first-time voters, their participation is likely to increase.

It also appears politicians have failed to acknowledge that, every four years, individuals who make up the majority of the $18-24$ year-old population have never been engaged in the election process. Essentially, this group is a revolving door of new potential voters who have never been courted by a campaign. This group is continually evolving, seeking new types of entertainment and engagement. Any method which has previously been used to mobilize youth is likely to be seen as unoriginal and unlikely to garner attention.

This research reveals several reasons why Hillary Clinton may have had a difficult time compelling young voters to turn out at the polls. Firstly, both candidates were significantly older with only one year between the two. As of Election Day, Hillary Clinton was 69 and Donald Trump 70. With both candidates being more than one standard deviation above the mean age of presidential candidates, it is unlikely young first-time voters would be able to identify with either candidate. Secondly, throughout her campaign, Clinton did address the issue of college affordability, however it seems that her direct concerted appeal to college-age voters did not happen until closer to Election Day. And thirdly, she used many of the same techniques and approaches as Barack Obama in 2008 and 2012. Nevertheless, with the passing of four and eight years respectively, these approaches have already become outdated to this technology savvy population.

\section{References}

Bassi, A., Morton , R. B., \& Williams, K. C. (2011). The Effect of Identities, Incentives, and Information on Voting. The Journal of Politics, 73, 558-571.

https://doi.org/10.1017/S0022381611000284 
Bobo, L., \& Gilliam Jr., F. D. (1990). Race, Sociopolitical Participation, and Black Empowerment. The American Political Science Review, 84, 337-393. https://doi.org/10.2307/1963525

Campbell, A., Converse P. E., Miller W. E., \& Stokes D. E. (1980). The American Voter. Chicago: University of Chicago Press.

Conover, P. J. (1984). The Influence of Group Identifications on Political Perception and Evaluation. The Journal of Politics, 46, 760-785. https://doi.org/10.2307/2130855

Daily Camera. (2008). Obama: Get Out That Vote; Candidate's Wife Addresses Young Voters at CU Rally.

Dolan, K. (1998). Voting for Women in the "Year of the Woman". American Journal of Political Science, 42, 272-293. https://doi.org/10.2307/2991756

Galston, W. A. (2001). Civic Knowledge, Civic Education, and Civic Engagement. In D. M. Shea, \& J. C. Green (Eds.), Fountain of Youth: Strategies and Tactics for Mobilizing America's Young Voters (pp. 95-114). Lanham, MD: Roman \& Littlefield.

Galston, W. A. (2004). Civic Education and Political Participation. PS: Political Science \& Politics, 37, 263-266. https://doi.org/10.1017/S1049096504004202

Greene, S. (1999). Understanding Party Identification: A Social Identity Approach. Political Psychology, 20, 393-403. https://doi.org/10.1111/0162-895X.00150

Holbrook, T. M., \& McClurg, S. D. (2005). The Mobilization of Core Supporters: Campaign, Turnout, and Electoral Composition in United States Presidential Elections. American Journal of Political Science, 49, 689-703. https://doi.org/10.1111/j.1540-5907.2005.00149.x

Huddy, L. (2001). From Social to Political Identity: A Critical Examination of Social Identity Theory. Political Psychology, 22, 127-156.

https://doi.org/10.1111/0162-895X.00230

Jackson, M. S. (2011). Priming the Sleeping Giant: The Dynamics of Latino Political Identity and Vote Choice. Political Psychology, 32, 691-716.

https://doi.org/10.1111/j.1467-9221.2011.00823.x

Kaufmann, K. M., Petrocik, J. R., \& Shaw, D. R. (2008). Unconventional Wisdom: Facts and Myths about American Voters. New York, NY: Oxford University Press.

Key, V. O. (1955). A Theory of Critical Elections. The Journal of Politics, 17, 3-18. https://doi.org/10.2307/2126401

Ledger (2000). Young Adult Tuning Out Election.

Leighley, J. E., \& Nagler, J. (2014). Who Votes Now? Demographics, Issues, Inequality, and Turnout in the United States. Princeton, NJ: Princeton University Press.

Lincoln Journal Star (1996). Issues, Candidates Keep Young Voters from Polls.

Matson, M., \& Fine, T. S. (2006). Gender, Ethnicity, and Ballot Information: Ballot Cues in Low-Information Elections. State Politics \& Policy Quarterly, 6, 49-72.

https://doi.org/10.1177/153244000600600103

Oakes, P. (2002). Psychological Groups and Political Psychology. Political Psychology, 23, 809-824. https://doi.org/10.1111/0162-895X.00308

Pittsburgh Post-Gazette (2000). Families Valued, Singles Ignored.

Pittsburgh Post-Gazette (2008). Gambling on the Youth Vote; If Obama Wins the White House, Chances are that Young Voters Will Have Put Him There.

Plutzer, E. (2002). Becoming a Habitual Voter: Inertia, Resources, and Growth in Young Adulthood. American Political Science Review, 96, 41-56.

https://doi.org/10.1017/S0003055402004227 
Pomante II, M. J., \& Schraufnagel, S. (2015). Candidate Age and Youth Voter Turnout. American Politics Research, 43, 479-503. https://doi.org/10.1177/1532673X14554829

Sarasota Herald-Tribune (2008). Election to Test Youth Strategy; Payoff; Obama Campaign Has Engaged Young Voters, But Will They Vote? Election Will Put Youth Strategy to Test.

Shea, D. M., \& Green, J. C. (2007). Tales from the Trenches: Party Orgainzations That Are Connecting with Young Citizens. In D. M. Shea, \& J. C. Green (Eds.), Fountain of Youth: Strategies and Tactics for Mobilizing America's Young Voters (pp. 49-77). Lanham, MD: Roman \& Littlefield.

St. Louis Post-Dispatch (1992). Economy Keeps Bush Behind in Poll Assorted Pressures Lead Younger Voters to; Take Interest in Presidential Election.

St. Louis Post-Dispatch (1992a). Dim Future Some Young Voters Not Optimistic, Claim Leaders Ignored Generation.

Sundquist, J. L. (1973). Dynamincs of the Party System: Alignment and Realignment of Political Parties in the United States. Washington: Brookings Institution.

Tajfel, H., Billing, M. G., Bundy, R. P., \& Flament, C. (1971). Social Categorization and Intergroup Behavior. European Journal of Social Psychology, 1, 149-178. https://doi.org/10.1002/ejsp.2420010202

The Atlanta Journal and Constitution (1992). What They're Saying on the Campaign the Comics Carson and Company Skewer the Candidates.

The Capital Times (2008). Advantage Obama; Young, Trained Political Organizers Are Blanketing the State for Barack. Where Is Jon McCain's Field Organization?

The Globe and Mail (1992). Republicans Find Ray of Hope in Latest Polls, Bush Gaining Ground, But Clinton far Ahead in Electoral College Vote.

The Globe and Mail (1992a). Swinging to a Democratic beat U.S. Election: In a Year in Which Arsenio Hall Carries as Much Clout as Ted Koppel, Young Voters Are Registering in Increasing Numbers.

The Guardian (1992). First-Time Voters Tune into Clinton; The Usually Apathetic Young Are Flocking to the Democrats.

The Guardian (1996). As Youth Vote Swells, Activists Take up the Slack; Jonathan Freedland in Cambridge, Massachusetts, Unravels the Mystery of Generation X.

The New York Times (1996). Young Voter, Diverse and Disillusioned, Are Unpredictable in '96 Race.

The Ottawa Citizen (2000). American Youth Ignore Election: With Voter Apathy at an All-Time High, Generation Y Leads the Way.

The Philadelphia Daily News (2008). They're Registered, But Will Young Voters Vote?

The Philadelphia Inquirer (1996). Youngest Voters Are Ready to Make Their X, But This Election, None of the Presidential Candidates is Courting Their Favor.

The Straits Times (2000). The Bush Dynasty.

The Washington Post (1992). Young Voters Appear to Be Shifting A way from the Republican Party.

The Washington Post (1992a). Dan Quayle: The Premeditated Surprise; How Young Senator Executed Game Plan to Becomes Bush's Running Mate in 1988.

USA Today (1992). Exit Poll: Economy Is Clinton's Magic Wand.

USA Today (1996). Youth Vote Still Is up for Grabs, Poll Analysts Say.

Verba, S., Scholzman, K. L., \& Brady, H. E. (1995). Voice and Equality. Cambridge, MA: 
Harvard University Press.

Wattenberg, M. (2012). Is Voting for Young People (3rd ed.)? New York, NY: Pearson Longman.

Zoltan, H., \& Trounstine, J. (2005). Where Turnout Matters: The Consequences of Uneven Turnout in City Politics. The Journal of Politics, 67, 515-535.

https://doi.org/10.1111/j.1468-2508.2005.00327.x 